\title{
Molecular Microbiological Characterization of Preterm Neonates at Risk of Bronchopulmonary Dysplasia
}

\author{
MATTHEW S. PAYNE, KEVIN C. W. GOSS, GARY J. CONNETT, TANOJ KOLLAMPARAMBIL, JULIAN P. LEGG, \\ RICHARD THWAITES, MARK ASHTON, VICTORIA PUDDY, JANET L. PEACOCK, AND KENNETH D. BRUCE
}

\begin{abstract}
Pharmaceutical Science Division [M.S.P., K.D.B.], School of Biomedical and Health Sciences, King's College, London, SE1 9NH, United Kingdom; Department of Paediatrics [G.J.C., J.P.L.], Southampton General Hospital, Southampton, SO16 6YD, United Kingdom; Neonatal Intensive Care Unit [T.K., V.P.], Princess Anne Hospital, Southampton, SO16 5YA, United Kingdom; Neonatal Intensive Care Unit [K.C.W.G., R.T., M.A.], St Mary's Hospital, Portsmouth, PO3 6AD, United Kingdom; and Public Health Sciences and Medical Statistics [J.L.P.], School of Medicine, University of Southampton, SO16 6YD, United Kingdom
\end{abstract}

\begin{abstract}
The role of infection in bronchopulmonary dysplasia (BPD) is unknown. We present an observational study of 55 premature infants born weighing less than $1.3 \mathrm{~kg}$ within two level III neonatal intensive care units. Endotracheal aspirates (ETA) and nasogastric aspirates (NGA) were studied with denaturing gradient gel electrophoresis (DGGE) profiling to elucidate the total bacterial community, and species-specific PCR was used to detect the presence of Mycoplasma hominis, Ureaplasma urealyticum, and Ureaplasma parvum. DGGE identified bacterial species in 59\% of NGA and ETA samples combined. A diverse range of species were identified including several implicated in preterm labor. Species-specific PCR identified M. hominis in $25 \%$ of NGA and $11 \%$ of ETA samples. Among the 48 infants surviving up to 36 wk-postconceptual age, ordinal logistic regression showed the odds ratio for BPD or death where Ureaplasma was present/absent as 4.80 (95\% CI 1.15-20.13). After adjusting for number of days ventilated, this was reduced to $2.04(0.41-10.25)$. These data demonstrate how the combined use of DGGE and species-specific PCR identifies a high exposure in utero and around the time of birth to bacteria that might be causally related to preterm delivery and subsequent lung injury. (Pediatr Res 67: 412-418, 2010)
\end{abstract}

Iising mprovements in neonatal intensive care have resulted in increased survival after extreme preterm delivery. Such infants are at risk of long-term complications. Despite the early use of ventilation and surfactant replacement, significant numbers suffer respiratory morbidity as a result of bronchopulmonary dysplasia (BPD) or neonatal chronic lung disease. The etiology of BPD is multifactorial, and a number of factors including mechanical ventilation, hyperoxia, and chorioamnionitis have been implicated (1). Previous studies have suggested that perinatal infection might be important in the development of this condition through mechanisms of inflammatory lung injury. A number of bacterial species have been implicated, including genital Ureaplasma spp, which the neonate might be exposed to perinatally (2-8). The evidence for the role of these organisms is inconsistent. Although some studies have suggested that antenatal exposure to Ureaplasma spp might be causally related to the development of BPD,

Received May 20, 2009; accepted November 28, 2009.

Correspondence: Gary J. Connett, M.D., Department of Paediatrics, Southampton University Hospitals NHS Trust, Tremona Road, Southampton, SO16 6YD, United Kingdom; e-mail: gary.connett@ suht.swest.nhs.uk

Support by the British Lung Foundation, Lung Disease in Children grant. others have shown no association (9-11). Studies have also investigated the presence of Mycoplasma hominis in neonates at risk of BPD using PCR techniques $(9,12)$. This organism has been implicated in infectious illnesses including pelvic inflammatory disease, bacterial vaginosis, neonatal bacteremia, meningitis, and abscesses (13) but has been identified infrequently in samples from preterm neonates.

Investigating the role of infection in preterm neonates depends on the collection of appropriate microbiological samples. Nasogastric aspirates (NGA), obtained shortly after birth, are thought to be informative about perinatal exposure to microbes. Similarly, analyses of endotracheal aspirates (ETA) from those infants intubated for ventilatory support might inform about the continued presence of these bacteria within the airways and the acquisition of environmental microbes.

Most studies have used either genus or species-specific culture-based or PCR approaches to identify bacterial species. Few have attempted to identify all of the bacterial species present in samples $(7,8)$. By using $16 \mathrm{~S}$ ribosomal RNA gene analyses, Oue et al. (8) identified 22 bacterial species in ETA and NGA.

In this study, we aimed to extend these observations using denaturing gradient gel electrophoresis (DGGE) profiling, a culture-independent approach to characterizing the bacterial species composition of samples. In addition species-specific PCRs for Mycoplasma and Ureaplasma spp were used. These tests enabled characterization of bacteria in ETA and NGA obtained from preterm neonates within two Level III neonatal intensive care units. Microbial findings and perinatal risk factors were related to the development of BPD diagnosed by standardized clinical features.

\section{METHODS}

Subjects. After parental consent, 55 preterm infants requiring mechanical ventilation with a birth weight of less than $1300 \mathrm{~g}$ admitted to either the Princess Anne or St Mary's neonatal intensive care units within $24 \mathrm{~h}$ of delivery over a 12 -mo period were invited to participate. All patients required

Abbreviations: BPD, bronchopulmonary dysplasia; CoNS, coagulase-negative Staphylococci; DGGE, denaturing gradient gel electrophoresis; ET, endotracheal; ETA, endotracheal aspirate; NG, nasogastric; NGA, nasogastric aspirate 
ventilatory support for at least $24 \mathrm{~h}$ and fulfilled clinical and radiologic criteria for physician-diagnosed respiratory distress syndrome (RDS). Recruitment was dictated in part by the availability of the clinical investigators to obtain informed consent for participation. Children with obvious congenital anomalies including congenital heart disease other than patent ductus arteriosus were excluded. The study had site-specific local ethical committee approval (REC ref no. 06/Q1702/78). Conventional mechanical ventilation was initiated in all infants, and at least one dose of surfactant therapy was given to all except one infant according to standard protocols. Fifty of 55 infants received cefotaxime for $48 \mathrm{~h}$ after birth, pending the results of blood cultures taken on admission. Two received benzylpenicillin and gentamicin for $48 \mathrm{~h}$ after delivery in other units, and three did not receive antibiotics. High-frequency ventilation was used in those infants when conventional ventilation was insufficient to maintain acceptable blood gas chemistry. Infants were categorized according to whether they developed BPD using criteria for the National Institutes of Health definition (14). All infants requiring oxygen $>21 \%$ for at least $28 \mathrm{~d}$ were diagnosed with BPD. Infants who continued to require oxygen at 36 wk-corrected gestational age were classified as having moderate $\left(\mathrm{FiO}_{2}\right.$ $<30 \%)$ or severe $\left(\mathrm{FiO}_{2}>30 \%\right)$ BPD.

Sample collection. All infants had an NG tube passed within a few hours of birth. Up to $1 \mathrm{~mL}$ of gastric fluid was aspirated by syringe, transferred into a sterile universal container, and stored at $-80^{\circ} \mathrm{C}$. ETA were obtained through open suctioning after the first $24 \mathrm{~h}$ of life or sooner if clinically indicated. Infants were briefly disconnected from the mechanical ventilator, and a suction catheter was inserted into the distal tip of the ET tube. Negative pressure suction was used to obtain an aspirate that was collected into a sterile specimen trap. If no aspirate was obtained, the procedure was repeated after the instillation of up to $1 \mathrm{~mL}$ of $0.9 \%$ saline into the ET tube followed by five ventilator breaths. ETA was stored in the same way as NGA specimens. All ETA used in this study were obtained within the first $5 \mathrm{~d}$ of life.

Nucleic acid extraction. Samples were diluted 1:3 with $0.2-\mu \mathrm{M}$ filtered $1 \times$ PBS and centrifuged at $4^{\circ} \mathrm{C}, 5000 \times g$ for $20 \mathrm{~min}$. Supernatant was removed, and pellets were resuspended in $600 \mu \mathrm{L}$ buffer RLT (QIAGEN). Lysates were homogenized using disposable QIAshredder (QIAGEN) columns, and DNA was extracted using a QIAGEN AllPrep DNA/RNA Mini kit as per manufacturer's instructions for animal and human cells.

\section{PCR amplification}

Mycoplasma hominis. A 334-bp section of the 16S rRNA gene specific to $M$. hominis was amplified with primers RNAH1f and RNAH2r using standard PCR conditions consisting of $25 \mu \mathrm{L}$ REDTaq Ready Mix PCR Reaction Mix (containing 1.5 U TaqDNA polymerase, $0.2 \mathrm{mM}$ of each dNTP, and $1.5 \mathrm{mM}$ $\mathrm{MgCl}_{2}$; Sigma Chemical Co.-Aldrich), $0.2 \mu \mathrm{M}$ of each primer (final concentration), 50-100 ng template DNA, and nuclease-free water (Ambion) to a final volume of $50 \mu \mathrm{L}$. DNA amplification reactions consisted of an initial denaturation at $95^{\circ} \mathrm{C}$ for $4 \mathrm{~min}$, followed by 35 cycles of $95^{\circ} \mathrm{C}$ for $50 \mathrm{~s}, 56^{\circ} \mathrm{C}$ for $50 \mathrm{~s}$, and $72^{\circ} \mathrm{C}$ for $50 \mathrm{~s}$, with a final extension at $72^{\circ} \mathrm{C}$ for $3 \mathrm{~min}$.

Ureaplasma urealyticum. The multiple-banded antigen (MBA) gene of $U$. urealyticum was amplified with primers UMS-125f and UMA226r using standard PCR conditions. This primer set can produce PCR amplicons of either $403 \mathrm{bp}$ or $448 \mathrm{bp}$ depending on the serotype of the strain. Of the 14 described serotypes of $U$. urealyticum, serotypes $1,3,6$, and 14 , which form biovar 1 (parvo biovar-Ureaplasma parvum), produce an amplicon of 403 $\mathrm{bp}$, whereas the remaining 10 that form biovar 2 (T960) produce an amplicon of $448 \mathrm{bp}$. DNA amplification reaction conditions were as per M. hominis.

16S rRNA gene. Bacterial 16S rRNA genes were amplified with primers $357 f$ (conserved for domain Bacteria, Escherichia coli positions 341-357) and 907rM (universal conserved primer, E. coli positions 907-926) using standard PCR conditions. A GC-clamp was attached to the $5^{\prime}$ end of the $357 \mathrm{f}$ primer $(15,16)$. The GC-clamp used was a 40-bp string of guanine and cytosine nucleotides. These are resistant to denaturing and, thus, stop complete separation of the strands of DNA, so that they remain fixed on the gel plate at the site where they are denatured. The primers amplify a 586-bp section of the 16S rRNA gene of members of the domain Bacteria, including the highly variable V3-V5 region. DNA amplification reactions were subjected to an initial denaturation at $94^{\circ} \mathrm{C}$ for $5 \mathrm{~min}$, followed by 10 touchdown cycles of $94^{\circ} \mathrm{C}$ for $1 \mathrm{~min}, 65^{\circ} \mathrm{C}$ for $1 \mathrm{~min}$ (dropping $1^{\circ} \mathrm{C}$ each cycle), and $72^{\circ} \mathrm{C}$ for $3 \mathrm{~min}$. A further 20 cycles of $94^{\circ} \mathrm{C}$ for $1 \mathrm{~min}, 55^{\circ} \mathrm{C}$ for $1 \mathrm{~min}$, and $72^{\circ} \mathrm{C}$ for $3 \mathrm{~min}$ were carried out after the initial touchdown cycles, with a final extension at $72^{\circ} \mathrm{C}$ for $5 \mathrm{~min}$. PCR reactions were carried out in an MJ Research PTC-225 Peltier thermal cycler gradient (MJ Research). PCR products were visualized in a $1.5 \%$ agarose gel, stained with $0.5 \times$ Gel Red (final concentration), and stored at $-20^{\circ} \mathrm{C}$.

DGGE analysis. DGGE was performed using a Bio-Rad D-Code (BioRad) DGGE system. By using a pico-drop spectrophotometer, $\sim 60 \mathrm{ng}$ of PCR products were separated in a $6 \%$ polyacrylamide gel with a $40-80 \%$ linear gradient of urea and formamide by electrophoresis at $100 \mathrm{~V}, 60^{\circ} \mathrm{C}$ for $17 \mathrm{~h}$. Denaturing gradient gels were stained with $1 \times$ SYBR gold nucleic acid stain
(Molecular Probes) and captured using a Herolab UVT-20 M/W ultraviolet transluminator. Distinct bands were excised, placed in $100 \mu \mathrm{L}$ of nucleasefree water (Ambion), and stored at $4^{\circ} \mathrm{C}$ overnight to elute DNA. DNA was reamplified through PCR as previously described, and DGGE was performed to check band mobility. Original PCR products of correct mobility were subsequently sequenced as outlined below.

Sequencing analysis. U. urealyticum, $M$. hominis, and DGGE PCR products were sequenced with primers UMS-125f, RNAH1, and 907rM, respectively. Before sequencing, all PCR products were purified using a MinElute PCR Purification Kit (QIAGEN), as per manufacturer's instructions. Sequencing reactions were performed using $\mathrm{ABI}$ BigDye Terminator version 3.1 sequencing dye (Applied Biosystems), as per manufacturer's instructions by Macrogen, Inc., South Korea.

Statistical analysis. Fisher's exact test or $\chi^{2}$ test was used to compare proportions, and the Mann Whitney $U$ test was used to compare ordinal data between study groups. Relationships between microbial and clinical outcome parameters related to the development of BPD were explored using Spearman's rank correlation, and ordinal logistic regression was used to adjust relationships observed on unifactorial analysis for possible confounding factors. These analyses were performed using SPSS version 17 and Stata version 10

\section{RESULTS}

Fifty-five (boy:girl, 32:23) infants fulfilling study criteria were enrolled (Table 1). Only one family that was invited to participate refused consent, but in the Southampton unit, there were a number of missed eligible patients because of the limited availability of staff to recruit in addition to their clinical duties at the start of the study. Fifty-three had full outcome measures available after discharge. Two were lost to follow-up after transfers out of region. Infants were classified into group 0 , no BPD; group 1, mild BPD; group 2, moderate or severe BPD; and group 3, died after $36 \mathrm{wk}$ postconceptual age of respiratory causes related to BPD. Five infants who died within 36 wk-corrected gestational age and the two lost to follow up could not be categorized for BPD and were not included in outcome analyses. There were no significant differences in study populations and outcomes between the study centers.

DGGE analyses. NGA specimens were successfully obtained in 44 infants. Amplification of a c. 586-bp PCR product was successful in $61 \%$ (27 of 44 ) of samples, from which 26 produced visible profiles after DGGE. As represented by the number of bands (i.e., species) per sample, bacterial diversity was higher in Portsmouth than Southampton samples (mean bands/sample $=3.14$ versus 1.62 ). Sequences retrieved from DGGE profiles indicated there were few bacterial species common to both Portsmouth and Southampton NGA (Table 2). Fifty-five ETA samples were analyzed. Amplification of a c. 586-bp PCR product was successful in 57\% (32 of 56) of all samples tested. This represented 14 of 23 and 18 of 33 positive samples from Portsmouth and Southampton hospitals, respectively. All PCR products produced visible bacterial profiles after DGGE, and these were reproducible by repeated DGGE analyses (data not shown). Bacterial diversity was similar in Portsmouth and Southampton infants (1.63 versus 1.60 species per sample) with few common species (Table 3). Sequences related to the coagulasenegative Staphylococci (CoNS), Staphylococcus haemolyticus, and Staphylococcus epidermidis were most common. The nucleotide sequence data of all DGGE sequences appear in the Genbank database under the accession numbers FJ999768-FJ999861. The most common or- 
Table 1. Clinical characteristics (whole sample, $\mathrm{N}=55$ )

\begin{tabular}{|c|c|c|c|}
\hline & Portsmouth $(N=28)$ & Southampton $(N=27)$ & Both sites $(N=55)$ \\
\hline Gestational age (wk) & $26.3(23.0-30.0)$ & $26.1(23.4-29.4)$ & $26.2(23.0-30.0)$ \\
\hline Birthweight (g) & $781.3(405-1208)$ & $864.3(565-1300)$ & $822.1(405-1300)$ \\
\hline Male, n (\%) & $15(54)$ & $17(63)$ & $32(58)$ \\
\hline C-section, n (\%) & $12(43)$ & $11(41)$ & $23(42)$ \\
\hline Chorioamnionitis, n (\%) & $6(21)$ & $5(19)$ & $11(20)$ \\
\hline PROM (>24 hr), n (\%) & $8(29)$ & $3(11)$ & $11(20)$ \\
\hline \multicolumn{4}{|l|}{ Ventilation } \\
\hline Intubated (d) & $21.6(1-90)$ & $15.4(1-84)$ & $18.6(1-90)$ \\
\hline CPAP (d) & $29.8(0-78)$ & $39(0-91)$ & $34.3(0-91)$ \\
\hline Oxygen $(\mathrm{d})$ & $35.3(0-69)$ & $35.5(0-106)$ & $35.4(0-106)$ \\
\hline \multicolumn{4}{|l|}{ Outcomes, n (\%) } \\
\hline Survival to discharge & $24(86)$ & $21(78)$ & $45(82)$ \\
\hline Death & $2(7)$ & $6(22)$ & $8(15)$ \\
\hline Lost to follow-up & $2(7)$ & 0 & $2(4)$ \\
\hline \multicolumn{4}{|l|}{ In survivors, $\mathrm{n}(\%)$} \\
\hline BPD (none) & $3(12)$ & $2(10)$ & $5(11)$ \\
\hline BPD (mild) & $7(27)$ & $6(29)$ & $13(28)$ \\
\hline BPD (moderate and severe) & $14(54)$ & $13(62)$ & $27(57)$ \\
\hline \multicolumn{4}{|l|}{ Deaths } \\
\hline BPD (none) & 0 & 2 early deaths & 2 early deaths \\
\hline BPD (mild) & 0 & 3 deaths after $28 \mathrm{~d}$ & 3 deaths after $28 \mathrm{~d}$ \\
\hline BPD (moderate and severe) & 2 late deaths & 1 late death & 3 late deaths \\
\hline
\end{tabular}

PROM, prolonged rupture of membranes; CPAP, continuous positive airways pressure (mask or prongs).

Table 2. Microbial species identified from DGGE analysis of NGA based on partial (512-548 bp) $16 S$ rRNA sequencing

\begin{tabular}{|c|c|c|c|}
\hline & Data base accession number and alignment (907rM) (bp) & No. samples & Hospital \\
\hline Sneathia spp & (EU644479) 521/521 & 2 & Southampton/Portsmouth \\
\hline Haemophilus influenzae & (EU185490) 543/543 & 2 & Southampton/Portsmouth \\
\hline Lactobacillus iners & (AY526083) 542/546 & 2 & Southampton/Portsmouth \\
\hline Ureaplasma urealyticum & (U06094) 541/541 & 2 & Southampton \\
\hline Anaerococcus prevotii & (AF542232) 512/515 & 1 & Southampton \\
\hline Atopobium vaginae & (AF325325) 524/524 & 1 & Southampton \\
\hline Enterococcus faecalis & (EU710762) 545/545 & 1 & Southampton \\
\hline Prevotella timonensis & (DQ518919) 547/547 & 1 & Southampton \\
\hline Pseudomonas aeruginosa & (EU849119) 544/544 & 1 & Southampton \\
\hline Leptotrichia amnionii & (EF218612) 521/521 & 4 & Portsmouth \\
\hline Prevotella bivia & (L16475) 532/536 & 2 & Portsmouth \\
\hline Brevibacterium spp & (EU086808) 525/529 & 1 & Portsmouth \\
\hline Mycoplasma hominis & (M96660) 535/538 & 1 & Portsmouth \\
\hline Staphylococcus hominis & (EU071625) 545/546 & 1 & Portsmouth \\
\hline Streptococcus oralis & (EU156770) 541/548 & 1 & Portsmouth \\
\hline Ureaplasma parvum & (AF073458) 545/548 & 1 & Portsmouth \\
\hline Veillonella spp & (AY355141) 541/544 & 1 & Portsmouth \\
\hline
\end{tabular}

ganism identified in NGA specimens was Fusobacterium nucleatum, a recognized cause of bacterial vaginosis. The most common organism in ETA specimens was $S$. hemolyticus. There was no relationship between the presence of these organisms and the timing of sample collection or clinical outcomes. We could not analyze the presence of other organisms in relation to outcome as numbers were small. Similarly, the absolute presence of any organism as determined by DGGE in NGA and/or ETA samples did not relate to clinical outcomes.
PCR analyses. M. hominis was detected in 13\% (3) and 9\% (3) of ETA and 21\% (5) and 30\% (6) of NGA from Portsmouth and Southampton neonates, respectively (Table 4). After sequence analysis, all PCR products showed 99-100\% similarity to M. hominis (accessions M96660, EU443622). Ureaplasma spp were detected in approximately half of all samples. Amplicons of retrieved sequences of the MBA gene were sequenced in an attempt to tentatively assign serovar types to the Ureaplasma spp. All PCR products tested showed 99-100\% similarity to U. parvum, serovars 1 (AF056983), 3 
Table 3. Microbial species identified from DGGE analysis of ETA based on partial (519-547 bp) 16S rRNA sequence

\begin{tabular}{llcc}
\hline & Database accession number alignment (907rM) (bp) & Presence in samples & Hospital \\
\hline Staphylococcus haemolyticus & (EU659857) 545/545 & 9 & Southampton/Portsmouth \\
Corynebacterium pseudogenitalium & (AJ439348) 529/529 & 2 & Southampton/Portsmouth \\
Pseudomonas aeruginosa & (EU849119) 546/546 & 1 & Southampton/Portsmouth \\
Staphylococcus epidermidis & (EU834244) 545/545 & 5 & Southampton \\
Enterococcus faecalis & (EU710762) 547/547 & 3 & Southampton \\
Prevotella loescheii & (AY836508) 535/538 & 1 & Southampton \\
Pseudomonas stutzeri & (EU883663) 545/545 & 1 & Southampton \\
Ureaplasma parvum & (AF073458) 542/542 & 1 & Southampton \\
Fusobacterium nucleatum & (EU419226) 520/520 & 4 & Portsmouth \\
Prevotella bivia spp & (L16475) 536/536 & 2 & Portsmouth \\
Enterobacter spp & (EU693569) 545/545 & 1 & Portsmouth \\
Fusobacterium equinum & (EF447429) 519/520 & 1 & Portsmouth \\
Haemophilus influenzae & (EU185490) 543/543 & 1 & Portsmouth \\
Staphylococcus aureus & (FJ434471) 546/546 & 1 & Portsmouth \\
Staphylococcus hominis & (EU071625) 539/546 & 1 & Portsmouth \\
Streptococcus oralis & (EU156770) 546/546 & Portsmouth \\
\hline
\end{tabular}

Table 4. Numbers of Mycoplasma hominis and Ureaplasma spp in ETA and NGA

\begin{tabular}{lcccccc}
\hline & \multicolumn{6}{c}{ Sequence confirmed } \\
\cline { 2 - 8 } & M. hominis & \multicolumn{4}{c}{ U. parvum } & U. urealyticum \\
\hline Serovar & - & 1 & 3 & 6 & 4 & 9 \\
Portsmouth ETA & 3 & 4 & 5 & 0 & 2 & 0 \\
Southampton ETA & 3 & 3 & 2 & 3 & 0 & 0 \\
Portsmouth NGA & 5 & 3 & 5 & 1 & 1 & 1 \\
Southampton NGA & 6 & 4 & 3 & 2 & 1 & 0 \\
\hline
\end{tabular}

* Tentative serovar assigned based on differences in MBA gene sequences.

(CP000942), and 6 (AF056984); and U. urealyticum, serovars 4 (AF055363) and 9 (AF055367). U. parvum was most prevalent. The nucleotide sequence data of all M. hominis and Ureaplasma spp sequences appear in the Genbank database under the accession numbers FJ999914-FJ999929 and FJ999862-FJ999913, respectively.

Clinical outcomes. Spearman's rank correlation was used to explore the relationship between microbiological findings and clinical outcomes (Table 5). Of note was the significant correlation between the identification of Ureaplasma spp on ETA samples and subsequent poor outcome for BPD $(p=$ $0.029)$ and an inverse relationship for weeks of gestation ( $p=$ 0.027). There was no significant relationship for Ureaplasma spp found on NGA obtained shortly after delivery and either of these outcomes. The presence of Ureaplasma spp in ETA samples was also correlated with a more prolonged period of ventilation $(p=0.01)$. Ordinal logistic regression showed that the odds ratio for BPD or death where Ureaplasma was present/absent was 4.80 (95\% CI 1.15-20.13), but after adjusting for the number of days ventilated, this odds ratio was reduced to $2.04(0.41-10.25)$ and was no longer significant. As might be expected, there were significant associations between the development of more severe BPD and gestation $(p=0.001)$ and low birth weight $(p<0.001)$. BPD was also correlated with higher ventilatory pressures $(p<0.001)$ and development of patent ductus $(p=0.013)$.

Patients with identified organisms in NGA and ETA samples were grouped according to mode of delivery. There were no significant differences in the rate of isolation of Urea- plasma and Mycoplasma spp, but when DGGE results were compared for organisms that have previously been reported in association with bacterial vaginosis and/or amnionitis, microbes were more commonly found in the NGA samples from infants delivered vaginally compared with caesarean section $(p=0.02)$. Caesarian section was less common among those infants who were more preterm.

\section{DISCUSSION}

Although this is a small study focusing on a limited number of clinical variables, these data have demonstrated a complex picture with a wide range of bacterial species present in NGA specimens obtained shortly after birth and in subsequent ETA. Our findings are consistent with those reported by Oue et al. (8), although we were able to identify a larger number of species and a higher prevalence of Ureaplasma spp and $M$. hominis in our more preterm population. This is consistent with our finding that the identification of Ureaplasma spp in ETA was negatively associated with weeks of gestation $(p=$ 0.027).

Ureaplasma spp are among the most common organisms isolated from the urogenital tracts of women, and so their frequent presence in ETA and NGA samples was not surprising. Some reports suggest that they can be isolated from cervicovaginal secretions in up to $80 \%$ of healthy women (13). Ureaplasma spp have long been associated with preterm labor and chorioamnionitis, two of the major risk factors for BPD. Although this study found an association between Ureaplasma spp in ETA and adverse respiratory outcomes $(p=$ 0.029), this could have occurred because of confounding variables, and the association lacked statistical significance after regression analysis taking account of number of days ventilated. Although ventilatory barotrauma after preterm birth is a well-recognized risk factor for BPD, it is possible that prolonged ventilation is needed because of airways inflammation caused by infection. We did not find an association between Ureaplasma spp in NGA and BPD, which might have been expected, given that this organism is likely to be acquired around the time of birth. However, this is consistent with previous studies and probably relates to either the sam- 
Table 5. Spearman's rank correlation for clinical outcome data $(\mathrm{N}=48)$

\begin{tabular}{|c|c|c|c|c|c|c|c|c|c|c|c|}
\hline Gender & $\begin{array}{c}\text { Birth } \\
\text { weight }(\mathrm{g})\end{array}$ & $\begin{array}{l}\text { Gestation } \\
\text { (wk) }\end{array}$ & $\begin{array}{l}\text { Mode of } \\
\text { delivery }\end{array}$ & PDA & $\begin{array}{l}\text { Mycoplasma } \\
\text { on NGA }\end{array}$ & $\begin{array}{c}\text { Mycoplasma } \\
\text { on ETA }\end{array}$ & $\begin{array}{c}\text { Ureaplasma } \\
\text { on NGA }\end{array}$ & $\begin{array}{l}\text { Ureaplasma } \\
\text { on ETA }\end{array}$ & $\begin{array}{l}\text { Outcome } \\
\left(\mathrm{BPD}^{*}\right)\end{array}$ & & \\
\hline-0.091 & 0.269 & 0.014 & -0.053 & 0.084 & -0.013 & -0.126 & -0.108 & -0.207 & -0.020 & $\begin{array}{l}\text { Correlation } \\
\text { coefficient }\end{array}$ & Hospital site \\
\hline \multirow[t]{19}{*}{0.539} & 0.065 & 0.927 & 0.722 & 0.572 & 0.928 & 0.393 & 0.465 & 0.158 & 0.890 & $\begin{array}{l}\text { Significance } \\
\text { (2 tailed) }\end{array}$ & \\
\hline & -0.183 & -0.097 & 0.032 & -0.167 & -0.121 & 0.025 & -0.022 & -0.030 & -0.121 & $\begin{array}{l}\text { Correlation } \\
\text { coefficient }\end{array}$ & Gender \\
\hline & 0.214 & 0.513 & 0.831 & 0.256 & 0.415 & 0.865 & 0.884 & 0.842 & 0.412 & $\begin{array}{l}\text { Significance } \\
\text { (2 tailed) }\end{array}$ & \\
\hline & & $0.596 \dagger$ & 0.168 & -0.211 & 0.123 & -0.188 & -0.012 & -0.260 & $-0.487 \dagger$ & $\begin{array}{l}\text { Correlation } \\
\text { coefficient }\end{array}$ & $\begin{array}{l}\text { Birth weight } \\
\text { (g) }\end{array}$ \\
\hline & & $<0.001$ & 0.253 & 0.151 & 0.404 & 0.201 & 0.933 & 0.074 & $<0.001$ & $\begin{array}{l}\text { Significance } \\
\text { (2 tailed) }\end{array}$ & \\
\hline & & & $0.524 \dagger$ & $-0.438 \dagger$ & 0.122 & -0.245 & 0.092 & -0.319 & $-0.474 \dagger$ & $\begin{array}{l}\text { Correlation } \\
\text { coefficient }\end{array}$ & $\begin{array}{l}\text { Gestation } \\
\text { (wk) }\end{array}$ \\
\hline & & & $<0.001$ & 0.002 & 0.411 & 0.093 & 0.535 & 0.027 & 0.001 & $\begin{array}{l}\text { Significance } \\
\text { (2 tailed) }\end{array}$ & \\
\hline & & & & -0.210 & 0.222 & -0.266 & 0.098 & $-0.356 \ddagger$ & -0.168 & $\begin{array}{l}\text { Correlation } \\
\text { coefficient }\end{array}$ & $\begin{array}{l}\text { Mode of } \\
\text { delivery }\end{array}$ \\
\hline & & & & 0.152 & 0.130 & 0.068 & 0.509 & 0.013 & 0.253 & $\begin{array}{l}\text { Significance } \\
\text { (2 tailed })\end{array}$ & \\
\hline & & & & & -0.053 & 0.151 & -0.172 & 0.177 & $0.356 \ddagger$ & $\begin{array}{l}\text { Correlation } \\
\text { coefficient }\end{array}$ & PDA \\
\hline & & & & & 0.719 & 0.306 & 0.242 & 0.229 & 0.013 & $\begin{array}{c}\text { Significance } \\
\text { (2 tailed) }\end{array}$ & \\
\hline & & & & & & $0.435 \dagger$ & -0.262 & 0.000 & -0.033 & $\begin{array}{l}\text { Correlation } \\
\text { coefficient }\end{array}$ & $\begin{array}{c}\text { Mycoplasma } \\
\text { on NGA }\end{array}$ \\
\hline & & & & & & 0.002 & 0.072 & 1.000 & 0.825 & $\begin{array}{l}\text { Significance } \\
\quad(2 \text { tailed })\end{array}$ & \\
\hline & & & & & & & -0.234 & 0.267 & 0.015 & $\begin{array}{l}\text { Correlation } \\
\text { coefficient }\end{array}$ & $\begin{array}{c}\text { Mycoplasma } \\
\text { on ETA }\end{array}$ \\
\hline & & & & & & & 0.110 & 0.067 & 0.917 & $\begin{array}{l}\text { Significance } \\
\text { (2 tailed })\end{array}$ & \\
\hline & & & & & & & & -0.183 & -0.225 & $\begin{array}{l}\text { Correlation } \\
\text { coefficient }\end{array}$ & $\begin{array}{c}\text { Ureaplasma } \\
\text { on NGA }\end{array}$ \\
\hline & & & & & & & & 0.214 & 0.124 & $\begin{array}{l}\text { Significance } \\
\text { (2 tailed) }\end{array}$ & \\
\hline & & & & & & & & & $0.316 \ddagger$ & $\begin{array}{l}\text { Correlation } \\
\text { coefficient }\end{array}$ & $\begin{array}{c}\text { Ureaplasma } \\
\text { on ETA }\end{array}$ \\
\hline & & & & & & & & & 0.029 & $\begin{array}{c}\text { Significance } \\
\text { (2 tailed })\end{array}$ & \\
\hline
\end{tabular}

* Bronchopulmonary dysplasia ranked outcomes: $0=$ no BPD; $1=$ mild BPD (in oxygen at 28 d postdelivery and no oxygen requirement at 36 wk postconceptual age); 2 = moderate or severe BPD (in oxygen at 36 wk postconceptual age and survival to discharge); $3=$ death after 36 wk postconceptual age with moderate/severe BPD.

$\dagger$ Correlation is significant at the 0.01 level ( 2 tailed).

\$Correlation is significant at the 0.05 level ( 2 tailed).

pling error or the threshold levels of detection for this organism (11). Consistent with previous studies, nearly all of the Ureaplasma spp detected were U. parvum (17).

The level of M. hominis in patients from both hospitals was higher than previously reported. Egawa et al. (9) found only $4.8 \%$ of ETA or NGA samples were positive for M. hominis, Couroucli et al. (18) reported only one in 89 ETA samples as positive. Wang et al. (12) recovered $M$. hominis plus $U$. urealyticum from ETA and NGA samples in 7\% of preterm infants. M. hominis has been associated with infections including bacterial vaginosis, pelvic inflammatory disease, neonatal bacteremia, meningitis, and abscesses (13). Examination of umbilical cord blood cultures in one study suggested that infants with positive $U$. urealyticum and/or M. hominis cultures were more likely to have neonatal systemic inflamma- tory response syndrome (6). We could not relate the presence of $M$. hominis to clinically relevant outcome parameters.

DGGE analysis identified larger numbers of species in NGA and ETA specimens than previously described $(7,8)$, but no obvious relationships between those were found within individuals comparing the two specimens. The clinical significance of these findings is uncertain. The presence of organisms per se did not relate to clinical outcome, but this could have been a compounding effect of mode of delivery. Previous studies have identified Atopobium vaginae, Fusobacterium spp, Bacteroides spp, Prevotella bivia, M. hominis, Leptotrichia amnionii, Megasphaera spp, Sneathia spp, Veillonella spp, Anaerococcus spp, and Ureaplasma spp in association with bacterial vaginosis $(19,20)$. All of these were identified at least once in our study. A similar culture and PCR/cloning 
study identified 17 bacterial taxa from preterm amniotic fluid samples (21). L. amnionii and Sneathia spp were identified in six of our NGA samples. These organisms have the potential to be intraamniotic pathogens and, thus, precipitate preterm delivery. Although chorioamnionitis commonly occurs without culture evidence of infection, our findings suggest this might occur because of the presence of previously unrecognized, uncultivated, or difficult-to-cultivate species. Future molecular studies focusing on cases of chorioamnionitis might usefully determine which species can precipitate preterm labor and have implications for antibiotic choices antenatally (22). A control group of term infants would help to clarify these issues. Our study showed that vaginal delivery increased the occurrence of pathogenic species in NGA. We suspect that this reflects a longer acquisition time for such organisms. Unfortunately, we did not collect data about the time between membrane rupture and delivery to explore this further.

The overall bacterial composition of ETA and NGA samples were very different. The reasons for this probably include postnatal nosocomial colonization of the endotracheal tube and changes in the relative numbers of organisms growing within the airway after they were acquired perinatally. Numbers were insufficient to determine whether the timing of ETA affected the relative distribution of organisms, but this might usefully be explored by analysis of specimens over a longer time period. CoNS were the most common organisms found in ETA samples. CoNS were only detected in one NGA. These organisms are widely reported in blood cultures from preterm neonates and were cultured in blood from six of our study neonates as a cause of sepsis. Their role in BPD is uncertain $(23,24)$. In this study, there was no association between the presence of CoNS in ET tubes and adverse respiratory outcomes, although five of six with positive CoNS blood cultures subsequently developed moderate or severe BPD. Similar associations have been previously reported (25). We suspect that this is not causal but reflects complications among longstay neonates independently at risk of BPD and neonatal sepsis.

Of note, Ureaplasma spp and M. hominis were more frequently detected in samples using species-specific PCR than 16S rRNA gene DGGE profiling. Han et al. (22) encountered similar issues comparing culture and 16S rRNA gene cloning. This difference might be due to a number of reasons. PCR biases might have resulted in differing efficiencies at which specific DNA sequences within mixed template samples were amplified (26). It is also possible that lower rRNA operon copy number of Ureaplasma spp and M. hominis compared with that of other bacterial species biased the amplification of templates containing these genera (27). Furthermore, the use of GC-clamps for DGGE analysis has been reported to lower the sensitivity of PCR and may have resulted in difficulties amplifying sequences from the Mollicutes class. Another explanation is that these differences occurred as a result of detection limits. That is, the levels of Ureaplasma spp and $M$. hominis in the samples where they were detected by speciesspecific PCR but not DGGE were very low and, therefore, below the detection threshold of DGGE, suggested to be $\sim 1 \%$ of the total population of a sample (28). Differences in detec- tion limits might also explain the lack of association between the presence of Ureaplasma spp in NGA and subsequent ETA. It is possible that organisms increase in number over time within the airway until eventually a proinflammatory "infective" number become present (7). Further studies should include sequential, PCR assays to elucidate whether Ureaplasma spp, in particular, are occurring within the airways in increasing numbers sufficient to cause infection. The use of recently published quantitative PCR protocols in longitudinal studies will help define the pathogenicity of Ureaplasma spp and other organisms in preterm neonates (29). Results might have important implications for antibiotic choices around the time of preterm delivery and postnatally.

Acknowledgments. We thank the parents and babies for their participation in the study. Also, we thank the medical, nursing, laboratory, and support staff in the neonatal intensive care units of Portsmouth and Southampton for their assistance and encouragement throughout the course of the study.

\section{REFERENCES}

1. Speer CP 2006 Inflammation and bronchopulmonary dysplasia: a continuing story. Semin Fetal Neonatal Med 11:354-362

2. Benstein BD, Crouse DT, Shanklin DR, Ourth DD 2003 Ureaplasma in lung. 2. Association with bronchopulmonary dysplasia in premature newborns. Exp Mol Pathol 75:171-177

3. Cassell GH, Waites KB, Crouse DT, Rudd PT, Canupp KC, Stagno S, Cutter GR 1988 Association of Ureaplasma urealyticum infection of the lower respiratory tract with chronic lung disease and death in very-low-birth-weight infants. Lancet 2:240245

4. Castro-Alcaraz S, Greenberg EM, Bateman DA, Regan JA 2002 Patterns of colonization with Ureaplasma urealyticum during neonatal intensive care unit hospitalizations of very low birth weight infants and the development of chronic lung disease. Pediatrics 110:e45

5. Colaizy TT, Morris CD, Lapidus J, Sklar RS, Pillers DA 2007 Detection of Ureaplasma DNA in endotracheal samples is associated with bronchopulmonary dysplasia after adjustment for multiple risk factors. Pediatr Res 61:578-583

6. Goldenberg RL, Andrews WW, Goepfert AR, Faye-Petersen O, Cliver SP, Carlo WA, Hauth JC 2008 The Alabama Preterm Birth Study: umbilical cord blood Ureaplasma urealyticum and Mycoplasma hominis cultures in very preterm newborn infants. Am J Obstet Gynecol 198:43.e1-43.e5

7. Kotecha S, Hodge R, Schaber JA, Miralles R, Silverman M, Grant WD 2004 Pulmonary Ureaplasma urealyticum is associated with the development of acute lung inflammation and chronic lung disease in preterm infants. Pediatr Res 55:61-68

8. Oue S, Hiroi M, Ogawa S, Hira S, Hasegawa M, Yamaoka S, Yasui M, Tamai H, Ogihara T 2009 Association of gastric fluid microbes at birth with severe bronchopulmonary dysplasia. Arch Dis Child Fetal Neonatal Ed 94:F17-F22

9. Egawa T, Morioka I, Morisawa T, Yokoyama N, Nakao H, Ohashi M, Matsuo M 2007 Ureaplasma urealyticum and Mycoplasma hominis presence in umbilical cord is associated with pathogenesis of funisitis. Kobe J Med Sci 53:241-249

10. Heggie AD, Bar-Shain D, Boxerbaum B, Fanaroff AA, O'Riordan MA, Robertson JA 2001 Identification and quantification of Ureaplasmas colonizing the respiratory tract and assessment of their role in the development of chronic lung disease in preterm infants. Pediatr Infect Dis J 20:854-859

11. Pandey A, Dhawan B, Gupta V, Chaudhry R, Deorari AK 2007 Clinical significance of airways colonization with Ureaplasma urealyticum in premature $(<34 \mathrm{wk})$ neonates. Indian J Med Res 125:679-684

12. Wang EE, Frayha H, Watts J, Hammerberg O, Chernesky MA, Mahony JB, Cassell GH 1988 Role of Ureaplasma urealyticum and other pathogens in the development of chronic lung disease of prematurity. Pediatr Infect Dis J 7:547-551

13. Waites KB, Schelonka RL, Xiao L, Grigsby PL, Novy MJ 2009 Congenital and opportunistic infections: Ureaplasma species and Mycoplasma hominis. Semin Fetal Neonatal Med 14:190-199

14. Ehrenkranz RA, Walsh MC, Vohr BR, Jobe AH, Wright LL, Fanaroff AA, Wrage LA, Poole K 2005 Validation of the National Institutes of Health consensus definition of bronchopulmonary dysplasia. Pediatrics 116:1353-1360

15. Muyzer G, Dewaal EC, Uitterlinden AG 1993 Profiling of complex microbialpopulations by denaturing gradient gel-electrophoresis analysis of polymerase chain reaction-amplified genes-coding for 16s ribosomal-RNA. Appl Environ Microbiol 59:695-700

16. Muyzer G, Smalla K 1998 Application of denaturing gradient gel electrophoresis (DGGE) and temperature gradient gel electrophoresis (TGGE) in microbial ecology. Antonie Van Leeuwenhoek 73:127-141

17. Waites KB, Katz B, Schelonka RL 2005 Mycoplasmas and Ureaplasmas as neonatal pathogens. Clin Microbiol Rev 18:757-789 
18. Couroucli XI, Welty SE, Ramsay PL, Wearden ME, Fuentes-Garcia FJ, Ni J, Jacobs TN, Towbin JA, Bowles NE 2000 Detection of microorganisms in the tracheal aspirates of preterm infants by polymerase chain reaction: association of adenovirus infection with bronchopulmonary dysplasia. Pediatr Res 47:225-232

19. Fredricks DN, Fiedler TL, Marrazzo JM 2005 Molecular identification of bacteria associated with bacterial vaginosis. N Engl J Med 353:1899-1911

20. Pretorius C, Jagatt A, Lamont RF 2007 The relationship between periodontal disease, bacterial vaginosis, and preterm birth. J Perinat Med 35:93-99

21. DiGiulio DB, Romero R, Amogan HP, Kusanovic JP, Bik EM, Gotsch F, Kim CJ, Erez O, Edwin S, Relman DA 2008 Microbial prevalence, diversity and abundance in amniotic fluid during preterm labor: a molecular and culture-based investigation. PLoS One 3:e3056

22. Han YW, Shen T, Chung P, Buhimschi IA, Buhimschi CS 2009 Uncultivated bacteria as etiologic agents of intra-amniotic inflammation leading to preterm birth. J Clin Microbiol 47:38-47
23. Bjorkqvist M, Soderquist B, Tornqvist E, Sjoberg L, Fredlund H, Kuhn I, Colque-Navarro P, Schollin J 2002 Phenotypic and genotypic characterisation of blood isolates of coagulase-negative staphylococci in the newborn. APMIS 110:332-339

24. Huang SY, Tang RB, Chen SJ, Chung RL 2003 Coagulase-negative staphylococcal bacteremia in critically ill children: risk factors and antimicrobial susceptibility. J Microbiol Immunol Infect 36:51-55

25. Liljedahl M, Bodin L, Schollin J 2004 Coagulase-negative staphylococcal sepsis as a predictor of bronchopulmonary dysplasia. Acta Paediatr 93:211-215

26. Chhibber A, Schroeder BG 2008 Single-molecule polymerase chain reaction reduces bias: application to DNA methylation analysis by bisulfite sequencing. Anal Biochem 377:46-54

27. Ohse H, Gobel UB 1987 Analysis of rRNA operons in Ureaplasma urealyticum. Isr J Med Sci 23:352-356 